\title{
UZ PRIJEPOR DUŠE I TIJELA - „VIĐENJE SV. BERNARDA" U HRVATSKOGLAGOLJSKOM OXFORDSKOM ZBORNIKU
}

dr. sc. Marija-Ana Dürrigl, Staroslavenski institut, duerrigl@stin.hr, Zagreb

izvorni znanstveni članak

UDK 821.163.42.09-97

003.349 .12

821.163.1

rukopis primljen: 27. 12. 2017.; prihvaćen za tisak: 29. 3. 2018.

U članku se razmatraju neki misaoni aspekti hrvatskoglagoljskoga proznog sastava Viđenje sv. Bernarda. To je jedno od možda najpopularnijih latinskih prenja u nas sačuvano u dvama zbornicima iz 15. stoljeća. Ono zrcali opća mjesta kršćanske srednjovjekovne duhovnosti, a odjeveno je u pokrenut, dramatičan dijalog. Premda se sudbina protagonista (upravo agonista) unaprijed zna, njihov prijepor obilježen je stilski uspjelim varijacijama pouke koja je u bitnom smislu upravljena primateljima: odvratite se od grešnosti navrijeme, jer pokojnik ne može biti pokajnik.

Ključne riječi: Viđenje svetoga Bernarda; prenja; hrvatskoglagoljska književnost; polifunkcionalnost; pokajanje

\section{Uvod}

Prenja su temeljena na izravnom sukobu (najčešće) dvaju suprotnih likova (personifikacija) i vjerojatno su najizravniji odraz onoga što suvremeni čitatelj doživljava kao dihotomiju, kao napetost života (da pozajmim Huizingin pojam) srednjovjekovnoga čovjeka. Razapet između svakodnevnice i obećanoga života u vječnosti, bio je u stalnoj borbi između 
Dobra i Zla - u toj bezvremenskoj borbi trebao je biti aktivan sudionik, a ne samo bespomoćna igračka. Tako su zborili i pisali srednjovjekovni moralni i teološki autoriteti, pa i književnici. Velika većina sačuvanih hrvatskoglagoljskih sastava nabožnoga sadržaja temelji se na toj suprotnosti; neka djela oprimjeruju kako se ne treba ponašati, dok druga djela daju primjer za udivljenje i imitaciju/nasljedovanje. „Binarnost medievalnog svjetonazora, sukobljenost entitetâ - dobra i zla, božanske vječnosti i ljudske prolaznosti, duhovnog i tvarnog [...] temelj je prikazanog antonimskog, simboličkog i alegorijskog strukturiranja svijeta književnog djela". ${ }^{1}$

Najizrazitija suprotnost i najizravnija tematizacija usuda nakon smrti jest prijepor između duše i tijela nakon smrti. U hrvatskoglagoljskoj je književnosti taj sastav pod naslovom „Videnie s(veta)go Brn(a)rda”2 zapisan u dvama zbornicima iz 15. stoljeća, u tzv. Oxfordskom zborniku (Oxford, Bodleian Library, Ms. Canon. Lit. 414) ${ }^{3}$ i Berčićevu zborniku (SanktPeterburg, GPB, Bč5). ${ }^{4}$ Za nj će se dalje u tekstu koristiti kratica VSB.

Riječ je o navodnom snoviđenju svetoga Bernarda koji je, usnuvši „duhovnim načinom” vidio sukob duše i tijela oko toga tko je kriv za vječnu osudu. Probudivši se, prestrašio se i pisa to v' knige nam' na nauk', kako zaključuje sveznajući pripovjedač. Promatrani ostvaraj bio je veoma popularan u europskoj srednjovjekovnoj književnosti, a izvorište mu je latinsko stihovano djelo koje se u stručnoj literaturi katkad naziva „Visio Philiberti”. Naime, o autorstvu izvornika u stručnoj literaturi nema konsenzusa - neki misle da mu je autor Robert Grosseteste, ili linkolnski biskup Philibert, ili pak Walter Map; s druge strane, neki drže da autori mogu biti i Francuzi Pierre de Blois ili Hildebert Lavardin. ${ }^{5}$ Pravi je izvor ipak adespotna staroengleska pjesma „Royal Debate” iz 10. stoljeća, kojoj nedostaje narativni prsten vizije ili snoviđenja. Mlađa latinska pjesma često nazivana „Visio Philiberti” (a poznata po prvom stihu Noctis sub silentio

\footnotetext{
1 Hercigonja 1975: 104.

2 Navodi iz glagoljskih tekstova donose se u latiničnoj transliteraciji po načelima za izradu Rječnika crkvenoslavenskoga jezika hrvatske redakcije (Staroslavenski institut, Zagreb), a kratice su razriješene.

3 Opis rukopisa u Tadin 1954: 139-144.

4 Usp. faksimil izvornika s transliteracijom u Glagoljski zbornik XV. stoljeća. Ruska nacionalna biblioteka, Zbirka Ivana Berčića, f. 67, Berč. br. 5, Zadar 2016. Obje je verzije u latiničnoj transliteraciji izdao Sambunjak 2000: 240-243.

5 Usp. Walter 1920: 65-80; Dinzelbacher 1981: 72; Dürrigl 2012 s bibliografijama.
} 
tempore brumali) iz 12. stoljeća najsličnija je ovoj glagoljskoj proznoj verziji; ${ }^{6}$ bila je među najpopularnijim srednjovjekovnim latinskim pjesmama. ${ }^{7}$ Vjerojatno je i tema odnosno oblik snoviđenja pojačala tu popularnost.

\section{VSB kao primjer polifunkcionalnoga djela}

Težište je ovoga kraćeg razmatranja na odnosu (duhovne, pastoralne) poruke/pouke i teksta, a manje na stilističkoj ili književnopovijesnoj raščlambi. Citat u kojem vidim ishodišnu antitezu oko koje se plete misaoni svijet promatranoga djela jest onaj što ga izgovara grešna duša na početku prenja, tužeći se na pokvareno tijelo: ê bih' veliko plemenito učinena i va obraz' boži bih' saz'dana a tobu bih' ukalana vsa i na pogibel' večnuû podana. Bog, naučavali su srednjovjekovni neoplatonisti, izravno stvara dušu i ona ima svoju vlastitost čak i dok je u jedinstvu s tijelom. ${ }^{8}$ Duša je ta koja sve oživljava i „odvojiva” je od tijela, a obuhvaća znanje, intelekt i volju. U navedenom citatu naslućuje se određena zaokruženost onoga što slijedi; ona je možda manje izrazita u sadržajnom i kompozicijskom smislu, a više u pouci i namjeri teksta.

Opća mjesta kršćanske moralke pojačavaju se tako što ih paradoksalno izgovaraju duša nakon smrti (a osuđena je na paklene muke) i mrtvo tijelo. Dijalog je to ne samo između ta dva suprotstavljena lika, već je to i dijalog s primateljima, kao u velikom broju naših nabožnih srednjovjekovnih tekstova. Naime, smrt je u srednjovjekovlju najčešće poimana kao tjelesni kraj, ali je metafizički ona bila početak, dveri kroz koja su pojedinci ulazili u vječnost.

Osim estetske, te praktičnih funkcija kao što su religiozno-eshatološka, djelo ima informativnu funkciju koja poučava o usudu duše nakon

6 „Hrvatskoglagoljski čakavski prijevod s nekim crkvenoslavenskim elementima nastao je, prema mišljenju E. Hercigonje, krajem 14. stoljeća, a čuva se u Oxfordskom zborniku iz 15. stoljeća i u Berčićevoj zbirci br. 5 iz 15. st. Osim u glagoljskim rukopisima, to se djelo nalazi i u dubrovačkome ćiriličnom Libru od mnozijeh razloga iz 1520. god. kao 'Čten'e Brnarda'. Usporedbom toga teksta s onim iz Oxfordskoga zbornika, Ivšić dolazi do zaključka da proizlaze iz iste glagoljske matice. Na osnovi glagoljskog predloška nastao je i tekst u latiničnome poljičkom Rudanovićevu rukopisu iz 1614. god., u kojem ima naslov 'Videnê sv. Brnardina' (sic!). Za taj tekst Franjo Fancev kaže da mjestimično bolje odražava pramaticu od tekstova u Oxfordskom zborniku i Libru." - Dürrigl 2016: 20-21.

7 Usp. Cartlidge 2006: 24.

8 Usp. Luscombe 1997: 82. Nije nam ovdje moguće ulaziti u podrobnosti srednjovjekovne misli o odnosu duše i tijela; usp. o tome Luscombe 1997 i Peklar 2015 s izborom iz relevantne literature. 
smrti. ${ }^{9}$ Estetska funkcija nije dominantna ali je prepoznatljiva i specifično ostvarena, jer je riječ je o funkcionalnom sinkretizmu ili „paralelizmu” 10 koji je tipičan za slavensku srednjovjekovnu književnost, gdje je vjerska potka uvijek vrlo značajna. Zato se može kazati da su stilski postupci u službi svih funkcija, a ne tek estetske; ornatio verbis nije samo za ugodu, nego i za pouku i poticaj; delectare (ako se može tako nazvati) i docere, a osobito movere idu ruku pod ruku! Međutim, valja makar usput ustvrditi: u stručnoj literaturi naglašava se kako su djela slavenske srednjovjekovne književnosti, pa tako i ona hrvatskoglagoljska, polifunkcionalna, da ih određuje funkcionalni sinkretizam. To jest točno, ali valja imati na umu da to nije samo njihova posebnost, jer su sva srednjovjekovna nabožna djela polifunkcionalna. Teško je pretpostaviti da je naše VSB imalo „više funkcija” od njegovih europskih verzija, ili da engleski „Dream of the Rood” i njemački „Muspilli” nisu imali više funkcija. ${ }^{11}$ Međutim, promišljanje o polifunkcionalnosti hrvatske srednjovjekovne književnosti poticajno je, pa i pri pokušaju oblikovanja novih žanrovskih obrazaca koji bi kod usustavljivanja polazili s korelativnoga pristupa, a tu je važna upravo polifunkcionalnost. Naime, i ona je razlogom tomu što se miješaju žanrovi i modusi, a nije samo posljedica toga miješanja. Važno je primijetiti da stilsko ukrašavanje (makar i ograničeno, kadšto gotovo shematsko) ne djeluje isključivo u smjeru praktično $\rightarrow$ estetsko, već i obratno. Ono što nazivamo ili doživljavamo kao estetsko potiče dojam i osjećaje, pojačava „reader response” te ističe temu. Ono dakle može biti i u funkciji praktičnoga, tj. pojačava dojam/učinak movere kad je riječ o nabožnom tekstu kakav je VSB.

Iz monologa duše razaznaje se da je tijelo bilo podložno raznim grijesima i manama koje su opća mjesta i liste kojih su stoljećima prenošeni u raznim knjigama, od priručnika za ispovjednike, do književnih djela: luxuria (gdi e zlato i sreb'ro tvoe), inepta laetitia i superbia (kadi domove $v$ kih' se ponošaše i veselaše; gdi e vlastel'stvo i sl(a)va tvoê ku se dičaše; vide tebe onomadne v(a)s svit' čtovaše i ti š nim' va velici vesel'i biše), amor saeculi (o telo nevol'no esi li sada veselo ot sega s(vê)ta), cupiditas (gdi e zlato i srebro tvoe ko

\footnotetext{
9 Tako npr. Schmidt 1987: 200.

10 Usp. nav. dj.: 190.

11 Katkad se i iz pomalo neočekivanih izvora kao što su neki ostvaraji obično svrstavani u fabliaux mogu iščitati socijalna i moralna kritika, npr. u Jeana Bodela i Watriqueta de Couvina, odnosno njihova „zabavnost” i komika kadšto imaju ozbiljan, duhovniji podtekst.
} 
pečal'no z'biraše), glutonia (nisu pri tebi raz'lične kuhine). Tijelo više ne može činiti zlo; ali ne zato što je mrtvo, već jer se odvojilo od zle duše! To je naoko paradoks, ali zapravo tijelo i duša tvore jedinstvo, zajedno čine ili dobro ili zlo. Međutim, isprike duše koje se čitaju/slušaju isprazne su i pogrešne: ona treba voditi tijelo, a ne dozvoljavati mu da se podaje grijehu, slabostima i iskušenjima. U riječima duše otkriva se da je ona još uvijek ogorčena, samosažalna i beznadna ( $o$ tugo bole biše i ne roditi se; plačite me $n(e) b(e) s a i$ z(e)mla i žaluite me v'se tvari). Štoviše, iz monologa obaju likova daje se naslutiti kako nemaju poniznosti i poslušnosti, pa zapravo ni pokajanja. Samosažaljenje jest prisutno, pa i rezignacija, ali ne i kajanje.

Na prvi se pogled sukob duše i tijela može činiti poput manihejskoga dualizma - međutim, riječ je o nečemu drugom. Čovjek je jedinstvo tijela i duše i kao takav je slika Božja i ima zadaću da su-djeluje u spasenjskoj povijesti svijeta, usprkos neposluhu i padu Adama i Eve. Njemačka mističarka Hildegarda iz Bingena ide korak dalje i čovjeka stavlja na vrh stvorenja - na dnu je materijalni, tvarni svijet; zatim slijede anđeli koji su čisto duhovna bića; čovjek je pak potpuno Božje stvorenje koje u sebi ujedinjuje tijelo (materijalno), razum, duh i dušu i tako je na vrhu "piramide” stvorenja. ${ }^{12}$

Poučna/informativna funkcija razaznaje se iz pomalo nemotiviranoga pitanja tijela o mogućnosti da se bogati iskupe! Tu je i socijalna kritika, vjerojatno usmjerena protiv raznih indulgencija: eda se ča bogatim' i plemenitim' praĉa ali ako e(stb) ko ufanie va otkuplenie pinezi i z(e)mlami ili inim' blagom' sego s(vê)ta? pita tijelo, ali mu duša odgovara da za one koji su osuđeni na paklene muke nema spasa ni otkupljenja - štoviše, parafrazira Sv. pismo: komu b(ogb) veĉe dae ot toga hoĉe veĉei služ'bi. ${ }^{13}$

Sve je u tekstu vrlo osjećajno. Ne samo da duša i tijelo govore emocionalno i emfatično (o velika žalosti; oime telo; o telo nevolno; o telo moe proklato; duša iz'liha vap'êše; otstupi ot mene raba tvoego koga nisu udržala kako bi se dostoêlo; i vele bolez'nivo poča uz'dihati), nego i vidjelac nakon buđenja ustraši se mnogo. Đavli su hiperbolično strašni: črneiši pakla [...] zubi k(a)ko grebeni imiûci [...] na čeli rogi imihu a iz' rogov' im' êd' štrcaše. Na početku toga opisa pripovjedač donosi tipičan topos neizrecivosti kih' g'rubosti vsi êzici ne bi mogli iz'govoriti ni pis'ci is'pisati. Njihova se ružnoća određuje izrazom

12 Usp. Zátonyi 2016: 68.

13 Parafraza biblijskoga mjesta Lk 12,48 i upute za opata iz 2. glave „Pravila sv. Benedikta”. 
grubostb koji se odnosi na nešto gnjilo, trulo, smrdljivo i nešto poput vihora. Imenica ovdje ima i simbolično značenje; taj je postupak češći u porabi epiteta: o telo nevol'no ili o telo moe proklato. Ne smije se zaboraviti da su i đavli izokrenuti nauk o Božjoj dobroti i pravednosti; onaj tko je odbacuje bit će odbačen i zarobljen od ovako strašnih đavala. Nameće se paralela s prenjem meštra Polikarpa i personificirane Smrti - ona koja je čovjekov neprijatelj u jednom mu času postaje pomoćnicom i poučava ga. Slično, barem načas, u VSB djeluju i đavli, pa u cerekanju duši poučavaju primatelje, „nas": mi s'mo tvoê gospoda zač' si naša dela činila [...] i mi ti nimamo česa inoga dati nego česa sami imamo dovole.

Retoričko-stilski postupci u VSB slični su onima u drugim hrvatskoglagoljskim prenjima: dijade i trijade, antiteza, topos neizrecivosti, hiperbolizacija u opisu đavala, retoričko pitanje, prisutnost gnomskoga stila, s biblijskim referencijama ili bez njih, npr. ere pisano e(stb) ako slip' slipa vodi v'êmu vpadeta se (usp. Mt 15,14). Uz to zamjetno je da je riječ o ritmiziranoj prozi, čemu doprinose i homeoteleuti i drugi oblici paralelizama, aliteracija i uporaba polisindeta. Ponavljaju se tu i neka opća mjesta srednjovjekovne književnosti i misaonosti. Ako se u slijedu događaja i naiđe na neki naoko nelogičan ili neizbrušen detalj, sve se zakriva time da je riječ o snu. Primjerice, kada se točno događa ovaj dramatičan sukob? Je li sudac već pogledao u knjigu u kojoj su zapisana sva (ne)djela duše, je li anđeo čuvar već prinio košaru s njezinim vrlinama i manama, je li duša već vagnuta? Ono o čemu maštovito i dojmljivo pripovijedaju sačuvane hrvatskoglagoljske (prijevodne, dakako) eshatološke vizije, ne doznaje se. Tek se naslućuje, jer na kraju dolaze đavli i uzimaju grešnu dušu kao svoj plijen, odvlače ju u propast, nema joj spasa.

Iz samosažalnih lamentacija duše i međusobnoga optuživanja jasno je kako dotični čovjek - jedinstvo duše i tijela - nije izvršio svoju zadaću da u Božjem svijetu živi na pobožan i odgovoran način. Zaključno se može kazati da raspleta među likovima nema. Za primatelja je rasplet u priči poticaj, uputa o potrebi pokajanja za života, on je implicitni „sugovornik” u ovom tekstu. U tom se smislu moguće djelomično suglasiti s Barbarom Peklar da je riječ o dijalogu kao zrcalu koje se stavlja pred unutarnje oči primatelja. ${ }^{14}$ Riječi koje se čitaju ili slušaju, dijalog ili opis, funkcioniraju kao zrcalo jer

\footnotetext{
14 „To pomeni da je dialog prej zrcalo kot konflikt. Spodbuja samoanalizo, pri kateri je človek [...] soočen sam s sabo" - Peklar 2015: 183. O literaturi zrcala, odnosno o zrcalu kao metafori u srednjovjekovnoj književnosti usp. još uvijek relevantnu studiju Bradley 1954.
} 
procesi čitanja i/ili slušanja nabožnih književnih djela imaju etički značaj. Etičnost se međutim ne sastoji samo u tome što tekstovi pripovijedaju o moralnim temama nego i u tome da svaki tekst poziva, potiče na određeni emotivni ali i voljni odgovor publike (srednjovjekovna intentio). ${ }^{15}$ Mistik Hugo od Sv. Viktora, primjerice, naglašavao je kako kod čitanja - dodala bih, i kod slušanja, premda u manjoj mjeri - primatelj ponajprije upravlja pozornost na egzemplarnost onoga o čemu se pripovijeda (ili o čemu se likovi spore), nakon čega slijedi pamćenje i „usvajanje” tih sadržaja, oblika i pouke.

Kraj spora među likovima vraća primatelja na ishodišnu viziju: vidihb telo mr'tvo ležeĉ' [...] i vidih' da duša toga tela pride. Krug se polako zatvara; misaoni zaključak vraća nas na početak teksta/rasprave, što naglašava spoznaju kako je disput među protagonistima bio suvišan jer nema pobjednika, oboje su gubitnici. Za razliku od ostalih hrvatskoglagoljskih prenja, u VSB se unaprijed zna sudbina likova i u njihovoj svađi nema pobjednika. Umjesto rješenja sukoba pojavljuju se đavli - dakle, temeljna je poruka teksta na početku i na kraju, a u međuvremenu se pred publikom odvijao dramatičan dijalog obogaćen odabranim retoričkofiguralnim elementima.

I ovaj je sastav, kao sva hrvatskoglagoljska prenja, teologija „odjevena” u dijalog (s pripovjednim elementima), u njemu se spajaju kazivanje, dijalog i tumačenje. Tumačenje je prisutno u narativnom prstenu, napose na kraju teksta, a prepoznatljivo je i u monolozima duše, pa i tijela. Iznose se tu opća mjesta - ali na dojmljiv način i u dojmljivu kontekstu, nakon smrti grešnika.

Kao vidjelac ovdje se navodi veliki crkveni autoritet sv. Bernard iz Clairvauxa, čime i sam tekst dobiva na težini. Kao da se nastojalo pojačati dojam „istinitosti” onoga o čemu se govori - međutim, u vizijama je istina cilj, a ne nužno i ishodište. Kognitivna i afektivna reakcija na tekst (čitan ili slušan) ovdje su snažno povezane. ${ }^{16}$ Spokoj i tišina zimske noći naprasno se prekidaju snoviđenjem u kojemu je mnogo govora, međusobnog optuživanja i nadmudrivanja koje je, u konačnici, izlišno: oboje je osuđeno na propast. Razgovor stoga ima svrhovitost „preko rampe” ili „onkraj stranice knjige” za primatelja. Trebalo se postići poistovjećivanje s likovima, jer - držali su neki (primjerice sv. Augustin) - samo vlastiti grijesi (odnosno, sjećanje na njih i njihovo priznavanje) poticali su na kajanje i promjenu ponašanja. U toj su funkciji i tema, i oblik (dijalog) i retoričkofiguralni postupci.

\footnotetext{
15 Usp. o tome Carruthers 1998: 168 i dalje.

16 Usp. Dürrigl 2012.
} 


\section{3. „Sada” i „tada”; „on” i ,ja”/ „mi”}

Duša tijelu spočitava kako je nekoć, u nekom pretpostavljeno proživljenom zemaljskom životu „tada"17 bilo moćno, oholo i bogato, a sada je svedeno na ništavilo i propadanje. Kaže da je svaki grijeh činilo tijelo, pa zbog toga oboje idu u propast. No, tijelo odgovara naoko manje osjećajno i razboritije; duša je stvorena od Boga i treba biti gospodarica tijelu, stoga ona snosi prvotnu odgovornost za prijestup i zlo. Pitanje o mogućnosti da se čovjek nekako bogatstvom spasi ili otkupi od kazne nemotivirano je i služi više da se naglasi poruka o neizbježnosti osude za grešnike. I opet se tu sastaju „tada” i „sada” - ali primateljima je sada čas da shvate tu poruku i da se pokaju. Trebaju se odreći grešnoga $\mathrm{i}$ ispraznoga života, kako bi izbjegli kaznu. ${ }^{18}$ Đavli svojim strašnim riječima pojačavaju sve što je duša rekla, dapače ide se korak dalje. govorahu mi smo t’voê gospoda zač si naša dela činila [...] ti mniš da b(og)a zoveš' a n(a)s' zoveš zač n $n(a)$ ša dela činaše i v'saki ki čê dela čini toga ocem' zove. Nema spasa duši koja utaman (!) moli Boga jer je već osuđena na vječne muke. To đavli zaključuju gnomom v'saki ki čê dela čini toga ocem' zove i toga v' istinu sin e(stb). To je zapravo najjasniji poticaj da se putem straha publika potakne na pokajanje - upravo emotivni stasis za promjenu.

Ovaj tekst zrcali značajke prenja kao relativno stabilne tekstne skupine, ${ }^{19}$ a to su: verbalni sukob (manje ili više zaokružen) dvaju suprotstavljenih personificiranih likova; antiteza i binarnost kao temelj kompozicije, ali i idejno načelo; motivska suprotstavljenost; poučnost i alegoričnost; dramska napetost i mogućnost za izvedbu (performativnost). U VSB prepoznaju se suprotstavljenosti kao što su: gluha zimska noć - svađa likova; sada - tada (i za protagoniste i za likove); duša - tijelo; Božje zapovijedi - grešno odvajanje od Boga; iskazane mane - pretpostavljene (zanemarene) vrline; mogućnost spasa - truljenje i pakao; prolaznost - vječnost (s variranjem teme „ubi sunt"); nepokretnost noći - đavli koji aktivno muče dušu, itd.

Duša na početku rasprave kaže da je na pogibel' večnuû podana, što može funkcionirati kao setting za razgovor, kao neka duhovna i sadržajna

17 Prilozi „sada” i „tada” mogu zvučati pomalo razgovorno, ali su odabrani jer izrazi/pojmovi „sadašnjost” i „prošlost” mogu biti krivo shvaćeni, jer ne dijelimo srednjovjekovne nazore o vremenu, napose ne one koji se reflektiraju u nabožnim djelima. - Usp. o tome npr. Zátonyi 2015.

18 To je također opće mjesto u vizijama, usp. npr. Adams 2007: 15.

19 Bez obzira na to jesu li pisana u prozi kao VSB, prenje Isusa s đavlom ili razgovor duše i misli, ili u stihu kao rasprava dobroga i zloga anđela, te Marije i Isusova križa. 
mizanscena. To međutim dovodi u pitanje smisao prepiranja: čemu svađa i međusobne optužbe? No, budući da je prenje VSB religiozno djelo ne samo po tematici nego i po nekim detaljima oblikovanja, po svome bitno retoričkom značaju - kauzalnost pa i svrhovitost nalaze se onkraj likova, pa čak i onkraj pripovjedača.

Zanimljiva je i kvaliteta ovoga teksta koji, kao i mnogi drugi tekstovi s vjerskom tematikom, kao da izravno povezuju događaje o kojima se pripovijeda s primateljima. „Tada” i „sada” kao antiteze ne tiču se tek likova u sukobu, već su u odnosu obrnute antiteze i s tim kategorijama zamišljene publike. „Tada” likova/protagonista (grešni život bez skromnosti i odgovornosti prema Bogu) uvjetuje njihovo „sada” (beznadan status - tijelo je ostavljeno propadanju, a duša mora u pakao). U tome „sada” međutim kao da je uključen primatelj koji bi trebao svoje „sada” (pretpostavljeni grešni život) promijeniti kako bi njegovo „tada” bilo drukčije, odnosno da se spasi. U tom su suprotstavljenom odnosu (vremenski, ali i uzročno) i „ono kako jest” i „ono kako treba biti” - potonje je prisutno upravo u antitetičkoj izvrnutosti onoga kako jest, upravo kao neizrečena ali prisutna potencijalna energija. Ona je oblikovana kroz riječi duše: a ê bih' veliko plemenito učinena i va obraz' boži bih' saz'dana - to je ishodište koje se izokrenulo zbog grijeha: $a$ tobu bih' ukalana v'sa i na pogibel' večnuû podana. Doslovce je to ostvarenje onoga što Grgur Veliki smatra zrcalom, tj. vjernik može u umjetničkim djelima prepoznati svoju izopačenost i rugobu. ${ }^{20}$ Kroz riječi duše i tijela slušatelji/čitatelji se prepoznaju kakvi jesu, a iz krajnjega usuda treba se iščitati kakvi ne bi smjeli biti. Dakle, i primatelji su u situaciji napetosti i razapetosti njihova vlastitog "sada” i „tada”, to je i antiteza života. Međuprožimanje „tada” i „sada” tu se također spaja s odnosom „svi mi” i „ja”, a to je značajka cjelokupne eshatološke književnosti. VSB je, kao i druga naša prenja, upravljeno svima i govori o svakome - ta uopćenost kao posljedicu ima određenu tradicionalnost, ne samo u tematici već i u porabi stilskih postupaka i prepoznatljivih toposa. Nema individualnosti u smislu usmjeravanja pozornosti na pojedinačni usud ili događaj; on se uvijek promatra sa zrenika općega, odnosno pomoću alegorije i simbolike uzdiže se na razinu koja će biti namijenjena svima u određenoj zajednici (zamišljene publike). To ipak govori „svakome od nas”, pa se i tu krug zatvara. Općenitost, pa i svojevrsna shematičnost otvara panoramsko gledište u kojem se svaki pojedinac mogao prepoznati. I tu se pokazuje da

20 Usp. Bradley 1954: 109-110. 
su djela kao VSB religiozna ne samo po tematici već i po načinu na koji su oblikovana; njihova je retoričnost u smislu poučavanja i poticanja uvijek u prvom planu, pa (kao da) zastire estetski značaj.Od brojnih sačuvanih prijepora možemo se prisjetiti dramske igre (moraliteta) „Ordo virtutum” njemačke mističarke Hildegarde iz Bingena (1098. -1179.). Tamo su u suodnosu raskajana duša živoga (!) čovjeka i vrline (milost, razboritost, čistoća, hrabrost, pravednost i dr.), pa duša primjerice kaže: „Ah, ah! goruća žudnja proždrla me u grijesima i ne usudih se ući!", a vrline joj odgovaraju: „Ne boj se i ne bježi, jer Pastir dobri u tebi traži svoju izgubljenu ovcu [...] Želimo te vratiti i nećemo te napustiti i sve vojske nebeske raduju se zbog tebe". ${ }^{21}$ Dakle, ishod - ali zapravo i cijeli odnos suprotan je od onoga u VSB: $u$ tom se viđenju/prenju nebeske sile ne raduju, tamo sama duša pokojnoga (!) grešnika vapi Plačite me $n(e) b(e) s a i$ z(e)mla i biva prokleta. Oba su teksta iz redovničkoga misaonog ishodišta; no dok je „Ordo virtutum” nudio mrkvu, dotle VSB nudi batinu. U njemu su likovi pasivni, prikazani su kao da osjećaju, ali ne mogu više ništa učiniti.

\section{Performativnost „Viđenja sv. Bernarda”}

Ako se VSB sagledava kao moralitet, može se pretpostaviti i konkretna fizička izvedba, makar koliko „suzdržana” bila. O njoj nema povijesnih podataka, a niti nedvojbenih unutartekstnih signala - osim dakako pokrenutoga dijaloga i izravnoga obraćanja (autorskoga) pripovjedača zamišljenoj publici. To su bratiê, a ta riječ može označavati neku redovničku zajednicu, ili žakne, ili pak „sve nas”, opće molitveno kršćansko mi, tipično za ovu vrstu književnosti. Nameće se pitanje: je li to bila konkretna publika koja je slušala tekst? $\mathrm{Na}$ taj se način, naime, izravnim obraćanjem pojačava povezanost zajednice; da pozajmim omiljenu srednjovjekovnu figuru paregmenona, pojačava se zajedništvo zajednice. Način na koji se tekst zaključuje nalikuje propovijedi.

O auditivnoj recepciji teksta izravno svjedoči pripovjedač, u egzordijalnom dijelu: a mi to slišeĉe čuvaimo se. Prelekcija, čitanje naglas ili kazivanje može se pretpostaviti kao komunikacijska situacija, jer se izrijekom spominje

21 „Ach, ach! fervens dulcedo absorbuit me in peccatis, et ideo non ausa sum intrare”; „Noli timere nec fugere quia Pastor bonus quaerit in te perditam ovem suam" - cit. prema Hildegard von Bingen. Lieder - Symphoniae. 2012: 267, te dalje: „Volumus te reducere et nolumus te deserere, et omnis caelestis militia gaudet super te" - nav. dj.: 271 (prev. M.-A. D.). 
publika koja sluša, a ne "gleda” događaje. ${ }^{22}$ Pripovijedanje je u VSB svedeno na minimum, na „davanje riječi” likovima koji se svađaju, a prisutna je u (tankom) prstenu snoviđenja na koji se nadovezuje gotovo propovjedni zaziv primateljima u maniri dosta tipičnoj u našim nabožnim glagoljskim djelima.

Srednjovjekovna je kultura određena karakterom pred-pismenosti; ona je, kako ističe Tony Davenport, „not an oral but a performance culture”. ${ }^{23} \mathrm{U}$ tom je kontekstu čitanje naglas bilo skupni, komunalni doživljaj ili događaj. Naime, mi polazimo od prvenstva (za)pisanoga teksta, ali on je mogao biti dostupan publici putem slušanja - pisana i usmena kultura dugo su supostojale i međusobno se nadopunjavale. ${ }^{24} \mathrm{~Pa}$ ipak, ovakvi unutartekstovni signali usmenosti tek upućuju na mogućnost ili vjerojatnost izvedbe u izravnoj, živoj komunikaciji s primateljima, ali se ne mogu uzeti kao nedvojben dokaz tomu. Svojim je ukupnim oblikom VSB bilo upravo idealno da se na živi dramatičan način izvede pred publikom. Ne samo namjera da se napisano „predoči”, već napetost koja postoji u tekstu a ostvarena je vrhunskom kompozicijom i biranom porabom retoričkofiguralnih elemenata, pokazuje kako je autor imao namjeru na dramatičan način prenijeti poruku koju je smatrao bitnom za sve kršćane. Bez obzira na to je li tekst bio namijenjen redovničkoj zajednici ili široj publici - uostalom, postupak „širenja” horizonta primatelja kao da je per definitionem uključen u postupak prevođenja! - on je oblikovan tako da pokrene i da omogući „prijenos” s papira u duše, srca i misli primatelja na vrlo ekonomičan i učinkovit način. Upravo struktura teksta kao da poziva ne samo na smireno čitanje kao „davanje glasa riječima u knjizi”, već na pokrenuto čitanje u kojemu se različitim likovima (duši, tijelu, đavlima, pripovjedaču) može dati različita boja glasa, a možda se dodaju i geste i mimika (što napose vrijedi za govor iscerenih, brbljavih đavala). U VSB je zaista nemalo gesta i zvukova: uzdisaja i vapaja protagonista (od kojih tijelo čak telo podviže glavu hoteĉi govoriti), te cerekanja i pokreta đavala (tada pridosta .b. an'̧̂(e)la d'êvla [...] i timi kukami tu d(u)šu popadoše tere û k' paklu pom'časta [...] nad' nu zubi š'krih'tahu niki û tini vezahu a niki û vrucim' olovom' polivahu a niki û êdom' napaêhu).

22 Usp. Vitz, Freeman Regalado, Lawrence 2005. Bez želje da uopćavam, valja spomenuti kako su i neka djela koja imaju (naoko) malo signala performativnosti ili ih uopće nemaju bila čitana naglas, npr. „Liber vitae meritorum” Hildegarde iz Bingena (usp. izdanje Hildegardis Liber vitae meritorum 1995); to je bila literatura uz obrok u njezinim samostanima te u muškom samostanu u Villersu.

23 Davenport 2004: 4.

24 Usp. Adamska 2004: 29-30. 
Kako je riječ o prijevodu, valja poći od primata pisanoga teksta. Onaj koji govori, izvorni "govornik", na neki je način tekst. ${ }^{25}$ Razlike među dvama hrvatskim glagoljskim zapisima nisu takve da bi upućivale na postojanje različitih predložaka, već na ponešto drugačiju konkretnu „realizaciju” teksta. U čitanju naglas ili izvođenju tekst nudi dvije mogućnosti: u početnom dijelu tijelo leži mrtvo, a duša prilazi k njemu i počinje ga grditi; tijelo diže glavu i odgovara - tu je tjelesni moment $u$ izvedbi vjerojatno bio sveden na najmanju mjeru, jer je riječ o nepokretnosti vremena nakon tjelesne smrti, a prije konačne „odluke” o usudu u vječnosti. Sve je „prema vani” nepokretno, a uzburkanost i napetost događa se „unutra”, u svakome od suprotstavljenih likova. Njihovi su monolozi odulji, svatko ima mogućnosti i vremena (!) da kaže sve što misli i što ga tišti; nema izravna citiranja autoriteta (oba su lika usvojila opća mjesta kao svoje vlastite argumente), sve je emotivno, ali pomalo sjetno. Uzbuđenje koje se osjeća zapravo je strah od neizbježnoga, jer „sada” je sve već gotovo... Stoga se čini da je suzdržani način izvedbe za ovaj dio djela bio najprikladniji, kad je sve tjelesno koncentrirano na glas. Vjerojatno je da se boja i intenzitet glasa mijenjaju kad govori duša i kad govori tijelo. Ne pomišljam na mogućnost da su tekst kazivale dvije ili tri osobe. Vokalne su se nijanse najvjerojatnije primjenjivale kod čitanja naglas, kako bi se postigao jači učinak u onih koji su slišeĉe. U toj je riječi na koncu djela izrijekom spomenuta auditivna recepcija i izravna komunikacija publike s „čitačem”/ kazivačem, pa tako i s onim o čemu se sluša. Nedvojbeno je da izvedba, makar svedena na odmjereno, zatajno, suzdržano, ona koncentrira pažnju i um. Osim toga, izvedbom se stvara već spomenuto zajedništvo. Ono što se u različitim vrstama izvedbe (tj. izravne komunikacije) gleda i sluša zahtjevno je i s kognitivnog gledišta. Naime, „shvaćanje” i „usvajanje” izvedbe stimulira više različitih centara u mozgu (u usporedbi s tihim čitanjem „u sebi”). U času kada na scenu stupaju đavli i odvlače nesretnu dušu u pakao, način izvedbe mogao je postati znatno „tjelesniji” i uključiti mimiku, pokrete itd. Pod izvedbom bih pretpostavila onu kao u liturgijskoga kazivača, ali su možda tekst kazivala/čitala naglas dvojica? Ako tomu i nije bilo tako, ovaj dijalog nije bilo moguće izgovarati u monotonu, jednim glasom, bez gesta i mimike, a napose ne bez mijenjanja glasa. Riječ je o pretpostavkama, jer o konkretnoj izvedbi nema potvrde. Osim toga, iako to tek zahtijeva temeljitu

\footnotetext{
25 „... the author - stroryteller (or performer) repeats aloud what a written text „tells” him (when he has it in front of him)" - Varty 2005: 160.
} 
analizu, valja barem usput spomenuti da je otvoreno pitanje o tome kako su se hrvatski glagoljaši služili neliturgijskim zbornicima: jesu li oni bili namijenjeni za čitanje u sebi (na što bi upućivalo upozorenje čti ne drêmli „Petrisovu zborniku” iz 1468. g.), za čitanje naglas (drugima), ili pak za kazivanje tekstova koji su bili zapisani kako bi se naučili napamet? Vjerojatno je riječ o kombinaciji tih triju mogućnosti.

\section{Zaključni pogled}

Dijaloška forma i opća pouka mogu također biti neizravan indikator toga da je tekst prenja bio namijenjen da ga čuje (ili pročita) veći broj ljudi. Oxfordski zbornik u kojem je zapisano VSB sadrži više tekstova s eshatološkom tematikom (jedinu u nas zapisanu dužu verziju "Pavlova viđenja”, kraću verziju starozavjetne „Abrahamove vizije”, jedini naš prijevod „Čistilišta svetoga Patricija”), a sadrži još jedno iznimno popularno prenje, ono Isusa s đavlom, nekoliko Marijinih mirakula i veći broj tekstova koji se u latinskom sadržaju „Oxfordskoga zbornika” nazivaju sermo. ${ }^{26}$ To su bili tekstovi koji su se u nekoj prilici čitali naglas ili pak kazivali po sjećanju, primjerice na neki blagdan ili neku misu tijekom crkvene godine. Dakle, prenja kao što je VSB pokazuju ne samo teškoće žanrovskoga usustavljivanja (prenje ili moralitet), već ona nadilaze i klasičnu rodovsku podjelu jer stoje na susretištu pripovjednoga i dramskoga. Osim toga, razvidno je da poučnost i duhovna korist nabožnih tekstova uopće prelaze sve podjele i kategorizacije na žanrove, pa čak i na velike blokove „praktičnoga” i „estetskoga”, pa se postavlja pitanje svrhovitosti lučenja moralnopoučnoga od narativnoga.

VSB dramatičnim, osjećajno nabijenim dijalogom suprostavljenih likova, a koji je dijalog zapravo za njih suvišan, govori o tome kakva je sudbina čovjeka koji se za ovozemaljskoga života ne obrati, i to ne deklarativno ili vanjskom formom (duši ne koristi više što je Bogu katkad bogomolû poslužila jer sama zaključuje kad u zadnjem obraćanju tijelu kaže: da kada te hotih' na dobro obratiti ti ne hotiše pris'tati zato vim' da sam' kriva ot prav(a)dnih' putov' zabl(u)dila pokle imih' vlast' nad' tobu gnilim' telom' da tobu ê ne vladah'), već djelima, pokorom i dobročinstvima. I opet se razabire specifična kružnost VBS: tijelo ne samo da gnjili nakon smrti, već je od početka predstavljeno kao trulo (gnilim' telom') jer je sklono pohoti i drugim grijesima. Iz dušinih zaziva o nevolno t(e)lo, o telo nečisto, o telo nevol'no, o

26 Usp. opis rukopisa u Tadin 1954. 
telo moe proklato i tobu gnilim' telom' jasno se odražava negativan stav prema svemu tjelesnomu, ali pravedan će čovjek, smatralo se, i tu pronaći zrcalnu sliku kako se treba odnositi prema tijelu. Zato autorski pripovjedač stupa u prvi plan i na kraju govori primateljima glasom kakva propovjednika: a mi to slišeĉe čuvaimo se da ne vpademo v taku muku da g(ospo)dinb milostivi izbavi $n(a)$ s' ot d'êvla i privedi $n(a)$ s'v c(êsa)rstvo n(e)beskoe amenb.

U ovom obraćanju prepoznaje se još jedna antiteza: Bog je milostiv pokajnicima, a duša koja se svađala s tijelom sama je sebe bila osudila zlim djelima i neposluhom. Na tragu toga jasno se iščitava relacija tada i sada eshatološke književnosti koja se odnosi ne samo na aktere/likove, nego u djelo uvlači i publiku. Potreba iskrenoga pokajanja i pravovremena obraćenja temeljna je misao hrvatskoglagoljske verzije prenja „Viđenje svetoga Bernarda" namijenjena publici, jer pokojnik više ne može biti pokajnik.

\section{Literatura}

Adamska, Anna (2004) „The Story of Medieval Literacy: Old Sources, New Ideas", The Development of Literate Mentalities in East Central Europe (= Utrecht studies in medieval literacy, vol. 9), ur. Anna Adamska, Marco Mostert, Brepols, Turnhout, 13-47.

Adams, Gwenfair Walters (2005) Visions in Late Medieval England. Lay Spirituality and Sacred Glimpses of the Hidden Worlds of Faith (=Studies in the History of Christian Traditions, vo. CXXX), Brill, Leiden - Boston.

Bradley, Ritamary (1954) „Backgrounds of the Title Speculum in medieval Literature", Speculum 25, 110-115.

Carruthers, Mary (1998) The Craft of Thought. Meditation, Rhetoric and the Making of Images 400 - 1200, Cambridge University Press, Cambridge.

Cartlidge, Neil (2006) „In the Silence of a Midwinter Night: A Re-Evaluation of the Visio Philiberti", Medium Ævum 75, 24-45.

Davenport, Tony (2004) Medieval Narrative: An Introduction, Oxford University Press, Oxford.

Dinzelbacher, Peter (1981) Vision und Visionsliteratur im Mittelalter, Anton Hiersemann, Stuttgart.

Dürrigl, Marija-Ana (2012) „Bihb usnul' ... a ne spah' - san kao viđenje”, Prostori snova. Oniričko kao poetološki i antropološki problem, ur. Živa Benčić, Dunja Fališevac, Disput, Zagreb, 103-123. 
Dürrigl, Marija-Ana (2016) Eshatološke vizije u hrvatskoglagoljskoj književnosti. Poetičke i žanrovske značajke, Hrvatska sveučilišna naklada, Zagreb.

Glagoljski zbornik XV. stoljeća. Ruska nacionalna biblioteka, Zbirka Ivana Berčića, f. 67, Berč. br. 5 (2016) ur. Svjetlana O. Vjalova, Stalna izložba crkvene umjetnosti u Zadru - Sveučilište u Zadru, Zadar.

Hercigonja, Eduard (1975) Povijest hrvatske književnosti 2: Srednjovjekovna književnost, Liber - Mladost, Zagreb.

Hildegard von Bingen. Lieder - Symphoniae (2012) (prir. i prev. Barbara Stühlmeyer), Abtei St. Hildegard - Beuroner Kunstverlag, Rüdesheim/ Eibingen - Beuron.

Hildegardis Liber vite meritorvm (=Corpus Christianorum continuatio mediaevalis XC) (1995), ur. Angela Carlevaris, Brepols, Turnhout.

Luscombe, David (1997) Medieval Thought (= A History of Western Philosophy II), Oxford University Press, Oxford.

Peklar, Barbara (2015) „Obravnava srednjeveškega dialoga med dušo in telesom ter vprašanje dualizma”, Ars \& Humanitas 9, 2, 172-199.

Sambunjak, Slavomir (2000) Jezik i stil hrvatskih glagoljskih prenja, Književni krug, Split.

Schmidt, Wolf-Heinrich (1987) „Funktionen der altbulgarischen Literatur”, Gatung und Narration in der älteren slawischen Literaturen, ur. KlausDieter Seemann), Otto Harrassowitz, Wiesbaden, 185-205.

Tadin, Marin (1954) „Glagolitic Manuscripts in the Bodleian Library, Oxford”, Oxford Slavonic Papers V, 133-144.

Varty, Kenneth (2005) „Reading, Reciting and Performing the Renart”, Performing Medieval Narrative (ur. Evelyn B. Vitz, Nancy Freeman Regalado, Maryilin Lawrence), Boydell \& Brewer, Cambridge, 155-166.

Vitz, Evelyn Birge, Freeman Regalado, Nancy, Lawrence, Marilyn (ur.) (2005) Performing Medieval Narrative, Boydell \& Brewer, Cambridge.

Walter, Hans (1920) Das Streitgedicht in der lateinischen Literatur des Mittelalters, Oskar Beck, München.

Zátonyi, Maura (2015) „Tempus praesens. Benediktinische Entwürfe aus dem 12. Jahrhundert über das Verhältnis des Menschen zur Zeit", Unversehrt und unverletzt. Hildegards von Bingen Menschenbild und Kircehverständnis heute (= Eudiri Sapientia Bd. XII), ur. Rainer Berndt, Maura Zátonyi, Aschendorff Verlag, Münster, 99-120. 
Zátonyi, Maura (2016) „Einleitung”, Hildegard von Bingen. Prophetisches Vermächtnis - Testamentum propheticum, prev. i prir. Maura Zátonyi, Abtei St. Hildegard - Beuroner Kunstverlag, Rüdesheim/Eibingen Beuron, 8-70.

\section{SUMMARY \\ Marija-Ana Dürrigl \\ THE SOUL/ BODY DEBATE IN THE CROATIAN GLAGOLITIC OXFORD MISCELLANY "VISION OF ST. BERNARD”}

The paper considers some contemplative aspects of the Croatian Glagolitic prose text The Vision of St. Bernard. It originates from one of the potentially most popular Latin contrasts and is preserved in two Croatian Glagolitic miscellanies from the 15th century. It mirrors general aspects of the medieval Christian spirituality and is draped in a vibrant, dramatic dialogue. Although the fate of the protagonists (agonists, in fact) is known in advance, their argument is marked by stylistically successful variations of the teaching essentially addressing the receivers. The version of the work recorded in the "Oxford Miscellany" (Oxford, Bodleian Library, Ms. Can. Lit. 414) includes a dream vision (assigned to one of the most important medieval theologians and thinkers, St. Bernard of Clairvaux). At the end, the narrating author, in a manner typical of Croatian Glagolitic texts, directly addresses the audience with his lesson and a call to repentance. Similarly to other preserved Croatian medieval works of religious content, this work is also multi-functional: in addition to aesthetic qualities, it also has a clear edifying character. The text is largely composed as a dramatic debate/ contrast between the soul and the body of a dying sinner, engaged in a mutually accusatory debate as the soul is condemned to an ever-burning hell. The contrast includes a lot of emotions - the soul's part reflects all the sins committed by the dying man. The soul is engaged in self-pity and lamentation, without showing any sense of guilt or remorse. To that extent, this work serves as a mirror for the audience - they can recognize what they are like and what they should be like through the wording of the dialogue (which also has some features of performability), with its underlying message being a call to repentance.

Keywords: Vision of St. Bernard; contrasts/debates; Croatian Glagolitic literature; polyfunctionality; repentance 